\title{
FACTORS ASSOCIATED WITH ADOLESCENT PREGNANCIES AMONG SECONDARY SCHOOL STUDENTS. A STUDY FROM TANGA-TANZANIA.
}

\author{
By: Nyakubega Peter (MD 5, MUHAS-2008/2009)
}

\section{ABSTRACT \\ OBJECTIVE}

To assess the factors associated with adolescent pregnancies among secondary students at Tanga municipality.

\section{METHODOLOGY}

A cross sectional descriptive analytical study which targeted all girls in secondary schools at Tanga municipality,

\section{RESULTS}

Low socioeconomic status was found to be an important cause for adolescent pregnancies as $57.1 \%$ of respondents suggested. Other factors responsible were luxury and deprivation of education to girls ( $43.5 \%$ and $16.5 \%$ respectively). Source of reproductive health education was contrary to most previous studies as $82.6 \%$ reported to get it from parents and health centres, while schools and peer groups contributed only $29.1 \%$ and $7.2 \%$ respectively.

\section{CONCLUSION}

Parents and guardians are important source of reproductive health education to adolescents and useful for prevention of early pregnancies. Early marriages are not as much important as source of adolescent pregnancies.

\section{RECOMMENDATIONS}

I encourage parents/guardians, to educate their children on reproductive issues, and to increase access to education for girls, which is of paramount importance in preventing adolescent pregnancies.

\section{INTRODUCTION}

Pregnancy is a physiological process, presenting with history of missed period, fatigue, breast enlargement and tenderness, abdominal distension, nausea and vomiting together with light-headedness. Abdominal ultrasound, urinary or serum levels of HCG are confirmatory tests for pregnancy. When these happen at age of 19 years or below they are called adolescent or teenage pregnancies.

Factors which contribute to adolescent pregnancies include poverty, areas with low practice of human rights.

A study by Robert Berkow et.al. in 1999 showed that adolescent pregnancy is a multifaceted problem as it involves social, political, cultural, educational and economical factors. Some of the risks that the newborn babies are exposed to are premature delivery, cerebral palsies and mental retardations due to birth injuries. Adolescent pregnancies are associated with STDs, abortions and HIV/AIDS.

The adolescents who become sexually active need access to reliable contraceptive methods. Adolescent who are at risk and those with pregnancy and parenting need psychological support and proper information and motivation not to conceive again during adolescence. It is therefore important to tackle this challenge from all aspects i.e. social, political, cultural, educational and economical aspects.

\section{METHODOLOGY}

This was a cross-sectional descriptive analytical study, schools were listed to get three schools by random selection from which a sample of 200 was obtained by random choice of the classes. 
Data was collected using Swahili translated questionnaires. Data was analyzed using Epi Info programme.

\section{ETHICAL CLEARANCE}

Permission to conduct the study was obtained from the department of Biostatistics and Epidemiology -MUHAS
Identification letter from the Institute of Public Health to the Medical Officer of Tanga municipality

Every interviewed student was assured of confidentiality of the information given and that the information will be used for scientific purposes only.

\section{RESULTS}

Table 1: Factors associated with adolescent pregnancies

\begin{tabular}{|l|l|l|}
\hline Factor for pregnancy & Yes & No \\
\hline Low socioeconomic status & $128(57.1 \%)$ & $96(42.9 \%)$ \\
\hline Luxury & $97(43.5 \%)$ & $126(56.5 \%)$ \\
\hline Deprivation of education & $37(16.5 \%)$ & $187(83.5 \%)$ \\
\hline
\end{tabular}

Low socioeconomic status was the most contributing factor for adolescent pregnancies (57.1\%).

Table 2: Awareness on contraceptive methods

\begin{tabular}{|l|l|l|}
\hline Method & Yes & No \\
\hline Contraceptive pills & $136(60.7 \%)$ & $88(39.3 \%)$ \\
\hline Injections(Depo-Provera) & $91(40.6 \%)$ & $133(54.9 \%)$ \\
\hline Male condoms & $112(50 \%)$ & $112(50 \%)$ \\
\hline Female condoms & $93(41.5 \%)$ & $131(58.5 \%)$ \\
\hline Tubal ligation & $58(25.9 \%)$ & $166(74.1 \%)$ \\
\hline IUCD & $74(33 \%)$ & $150(67 \%)$ \\
\hline
\end{tabular}

Most students (60.7\%) were aware of contraceptive pills as the method of preventing unwanted pregnancies.

Table 3: Awareness of contraceptive methods with age

\begin{tabular}{|l|l|l|l|l|l|l|}
\hline Age(Total) & Contraceptive Pills & $\begin{array}{l}\text { Injection } \\
\text { (Depo-Provera) }\end{array}$ & $\begin{array}{l}\text { Male } \\
\text { condoms }\end{array}$ & $\begin{array}{l}\text { Female } \\
\text { condom }\end{array}$ & $\begin{array}{l}\text { Tubal } \\
\text { ligation }\end{array}$ & IUCD \\
\hline $\mathbf{1 3 - 1 5 ( 8 5 )}$ & $46(54.1 \%)$ & $21(24.7 \%)$ & $26(30.6 \%)$ & $24(28.2 \%)$ & $12(14.1 \%)$ & $17(20 \%)$ \\
\hline $\mathbf{1 6 - 1 8 ( 1 1 9 )}$ & $79(66.4 \%)$ & $60(50.4 \%)$ & $72(60.5 \%)$ & $58(48.7 \%)$ & $41(34.5 \%)$ & $50(42 \%)$ \\
\hline $\mathbf{1 9 + ( 2 0 )}$ & $11(55 \%)$ & $10(50 \%)$ & $14(70 \%)$ & $11(55 \%)$ & $5(25 \%)$ & $7(35 \%)$ \\
\hline
\end{tabular}

Knowledge of male and female condoms contraceptives was seen to increase with age.

Table 7: Source of reproductive health education

\begin{tabular}{|l|l|l|l|}
\hline Source of information & Yes & No & Total \\
\hline School & $65(21.1 \%)$ & $158(70.9 \%)$ & $223(100 \%)$ \\
\hline Parents and health centers & $185(82.6 \%)$ & $39(17.4 \%)$ & $224(100 \%)$ \\
\hline Peer groups & $16(7.2 \%)$ & $207(92.8 \%)$ & $223(100 \%)$ \\
\hline
\end{tabular}

Parents/Guardians and health centers are the main source of reproductive health education (82.6\%)

\section{DISCUSSION}

In this study it was found that the students considered low socioeconomic status as the main factor for adolescent pregnancy (57.1\%).This finding is relevant to that of Missouri report 1995 and Nobble J et al 1996, which found girls from families with economic hardships have high incidence of adolescent pregnancies. ${ }^{1}$ 
This study found that luxury and deprivation of education for girls as other reasons for adolescent pregnancy with $43.5 \%$ and $16.5 \%$ of students responding respectively, which goes hand in hand with John H. [1995], who reported that unwanted pregnancies were contributed by a wide range of factors, including financial problems - especially unemployment and poverty among girls, lack of information about sexual matters, exposure, too much leisure, illiteracy and low level of education among girls. ${ }^{2}$

Another interesting finding in this study is that no student responded to early marriage as a cause of early pregnancy. This is in contrary to WHO report (1998) which showed that about two-thirds of sub-Saharan African women gave birth before 20 years of age due to cultural norms which encourage early marriage and proving fertility at young age. ${ }^{3}$ Discrepancy above can be explained by the fact that WHO report is regional and the situation can vary locally. Also, this study involved students who are likely to come from literate community which does not practice early marriages for girls at young age.

On awareness of contraceptive methods, contraceptive pills were the most known method of prevention of unwanted pregnancy among students (60.7\%). This study also found that only $23.5 \%, 26.9 \%$ and $45 \%$ of students in age groups of 13-15,16-18 and 19+ respectively were having correct knowledge of days in which a woman can conceive, which is not satisfactory. This is equivalent to the study by Fundikira 1985, which found ignorance and misconception about the reproductive biology and contraception contributes significantly to high rates of pregnancies among sexually active adolescents.

Another finding from this study is the higher percentage of students who got reproductive health education from their parents/guardians and health centres (82.6\%), while those who got it from school and peer groups were only $29.1 \%$ and $7.2 \%$ respectively. This goes contrary to Muhondwa study done in Mtwara rural and Makete district in Tanzania (1999) which revealed that parents and schools were not among the source of sexual knowledge. ${ }^{4}$ The difference can be explained by the fact that the later study has been done about ten years past in rural community in contrast to this study which has been done in Tanga Urban community.

\section{CONCLUSION}

From this study it has been clear that parents/ guardians and health posts are important sources of reproductive health education to adolescents and hence useful for preventing adolescent pregnancies, in contrast to past studies which did not show this critical role of theirs. The finding that early marriages are not important cause of adolescent pregnancies is a line of research which future studies can undertake.

\section{RECOMMENDATIONS}

Parents and guardians should be encouraged to educate their children about reproductive health because they can do it better as this study has shown.

Increased chances for girls to acquire formal education will lower the problem adolescent pregnancies.

Knowledge on reproductive biology if taught in schools from elementary level will help greatly in combating the problem of early pregnancies.

\section{ACKNOWLEDGEMENT}

I like to give my sincere gratitude's to Dr.Wangwe who devoted his time and skills tirelessly which made my research a success.

Furthermore, I would like to thank the university through its department of Epidemiology and Biostatistics which made the study possible through its funding and coordination.

I would also like to acknowledge the support I got from the teachers of the schools where I did my study, for organizing the students for interview out of their own will.

Last but not least I give my appreciation to the students who volunteered to give their personal information for my study; they were really a cornerstone for my work.

\section{REFERENCES}

1. Nobble. J, influence of Economic hardship and poor performance in school by girls, 1996

2. John. H, Report on Unwanted pregnancy, 1995.

3. WHO (1998), Education levels and cultural norms influence pregnancy in Adolescents.

4. Muhondwa, Adolescent sexuality and HIV/AIDS in Mtwara and Makete district, 1999. 